\title{
SPECIFICS OF FINANCING PUBLIC PROCUREMENT IN THE REPUBLIC OF MOLDOVA IN THE CONTEXT OF OPTIMIZING PUBLIC FINANCE MANAGEMENT
}

\author{
Andrei MULIC 1 , PhD in Economics, Associate Professor, \\ Faculty of Economics Science, Department of Finance and Banking, \\ Moldova State University, \\ Galina ULIAN2, Doctor Habilitat in Economics, Professor, \\ Faculty of Economics Science, Department of Finance and Banking, \\ Moldova State University
}

DOI: https://doi.org/10.36004/nier.es.2021.1-03

JEL Classification: H42, H44, H57, G28

CZU: 339.186+336.5](478)

\section{ABSTRACT}

Public procurement is investigated in terms of results and maximum efficiency of allocation of financial resources of the national public budget. In the context of economic development, optimization of the management of public financial resources is based on improving the legislation on public procurement and the financing mechanism. Based on this, public procurement is a complex, multi-level, interdependent system, the functioning at the all public levels. The aim of the research is to conduct a comprehensive study of the main problems and features of public procurement financing in order to optimize public finance management at the national level and to develop recommendations for improving the public procurement system in the Republic of Moldova. The methodology is based on the structural research method. The article is based on a study of the public procurement system in the Republic of Moldova, analyzing its constituent elements. The analytical method was used to study the concept of public procurement. The study established the relationship between the ethical behavior of officials, the effectiveness of control and the implementation of information systems to optimize the system of financing public procurement in the Republic of Moldova. Proposals are presented to improve the efficiency of the public financing mechanism in the context of electronic public procurement procedures within the automated information system "State Register of Public Procurements" MTender.

Keywords: public procurement, public financial resources, financing mechanism, national public budgetary funds, budgetary allocations.

Achizițiile publice se cercetează din punctul de vedere al rezultatelor și eficienței maxime a alocării resurselor financiare ale bugetului public național. În contextul dezvoltării economice, optimizarea gestionării resurselor financiare publice se bazează pe îmbunătățirea legislației privind achizițiile publice și a mecanismului de finanțare. Rezultând din aceasta, achizițiile publice sunt prezentate ca un sistem complex, pe mai multe niveluri, de categorii interdependente, a cărui funcționare ar trebui să asigure distribuția optimă a resurselor financiare publice la nivel central și local. Scopul cercetării constă în realizarea unei cercetări complexe ale principalelor probleme și particularităților finanțării achizițiilor publice în scopul optimizării managementul finanțelor publice la nivel național și elaborarea recomandărilor pentru îmbunătățirea sistemului de achiziții publice în Republica Moldova. Metodologia aplicată se fundamentează pe metoda structurală de cercetare. Articolul se bazează pe studierea sistemului de achiziții publice în Republica Moldova, astfel analizînd elementele componente ale acestuia. Metoda analitică a fost utilizată pentru cercetarea conceptului de achiziții publice, precum și legislația în vigoare privind sistemul de achiziții publice. În cadrul cercetării a fost stabilită relația dintre comportamentul etic al funcționarilor, eficacitatea controlului și implementarea sistemelor

${ }^{1}$ ID ORCID 0000-0001-6207-1216 e-mail: andreimulic@yahoo.com

${ }^{2}$ ID ORCID 0000-0002-0117-8359 e-mail: galina_ulian@mail.ru 
informaționale pentru optimizarea sistemului de finanțare a achizițiilor publice în Republica Moldova. Sunt prezentate propuneri pentru îmbunătățirea eficienței mecanismului de finanțare publică în contextul procedurilor de achiziții publice electronice în cadrul sistemului informaţional automatizat "Registrul de stat al achiziţiilor publice" (SIA „RSAP”) MTender.

Cuvinte-cheie: achiziții publice, resurse financiare publice, mecanism de finanțare, fonduri bugetare publice naționale, alocații bugetare

Государственные закупки исследуются с точки зрения результатов и максимальной эффективности распределения финансовых ресурсов национального публичного бюджета. $B$ контексте экономического развития оптимизация управления государственными финансовыми ресурсами базируется на совершенствовании законодательства о государственных закупках и механизма финансирования. Исходя их этого, государственные закупки представляют собой сложную, многоуровневую, взаимозависимую систему, функционирование которой должно обеспечивать оптимальное распределение государственных финансовых ресурсов на центральном и местном уровнях. Цель исследования - провести комплексное исследование основных проблем и особенностей финансирования государственных закупок с целью оптимизации управления государственными финансами на национальном уровне и разработать рекомендации по совершенствованию системы государственных закупок в Республике Молдова. Примененная в статье методология основана на структурном методе исследования. Статья основана на исследовании системы государственных закупок в Республике Молдова, анализируя ее составные элементы. Аналитический метод был использован для исследования концепции государственных закупок, а также действующего законодательства о системе государственных закупок. В ходе исследования была установлена взаимосвязь между этичным поведением должностных лиц, эффективностью контроля и внедрением информационных систем для оптимизации системы финансирования государственных закупок в Республике Молдова. Представлены предложения по повышению эффективности механизма государственного финансирования в контексте электронных процедур государственных закупок в рамках автоматизированной информационной системы «Государственный регистр государственных закупок» (SIA «RSAP») MTender.

Ключевые слова: государственные закупки, государственные финансовые ресурсы, механизм финансирования, национальные публичные бюджетные фонды, бюджетные ассигнования.

\section{INTRODUCTION}

Currently, a system of legal norms has been developed in the Republic of Moldova, which regulates the relations regarding the introduction and implementation of a more efficient way of using budgetary funds - the public procurement system. The legal rules governing public procurement relations have developed and emerged in a relatively recent separate group. Therefore, the relationships associated with the procurement of goods and services at the state and local level are the most relevant.

Public procurement means the purchase of goods, the execution of works or the provision of services for the needs of one or more contracting authorities (art. 1 of Law no. 131 of 03.07.2015 on public procurement).

Therefore, public procurement is the purchase of goods (works, services) for the needs of state bodies using budgetary funds.

In the Republic of Moldova, there is a relatively large share of public procurement in the structure of national public budget expenditures, therefore, the issue of forming and developing an efficient system of organization and management of public procurement is of particular importance. 


\section{Hypothesis development:}

1. The public procurement process in the Republic of Moldova is a complex process focused on optimizing the use of public financial resources. This issue includes correcting gaps in national legislation and creating a transparent system that is resistant to political influences.

2. Improving the efficiency of the use of public financial resources must be achieved by implementing modern information systems and increasing the efficiency of public procurement financing at central and local level. This aspect includes the relationships between the ethical behavior of civil servants implementing public procurement, the effectiveness of interdepartmental, community, specialized control and the optimization of the share of public procurement in the gross domestic product.

\section{LITERATURE REVIEW}

The specialized literature examines in detail the determinants for compliance with the rules for financing public procurement (Dennis orobo and Willy, 2015) (Omagbon, 2016); (Sandada and Kambarami, 2016). These researches were realized using simplified scientific methods. Improving and developing simplified public procurement financing models contributes to the use of strategic models for a broader understanding of the key factors that explain compliance with regulatory requirements in the field of public procurement. This perspective will provide a strategic understanding of public finance management policy, in order to focus on more specific and important factors for improving public procurement legislation and optimizing the funding mechanism. The evaluation of the particularities of public procurement financing in the Republic of Moldova involves a systemic structural analysis to establish factors that influence the establishment of regulatory requirements in the field of public procurement. The

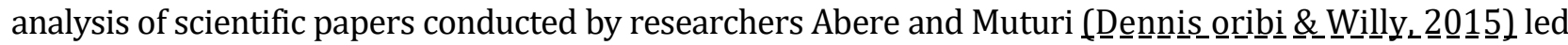
to the conclusion that the practices and mechanisms of financing public procurement have a significant impact on optimizing the management of public finances.

According to research by Gabriella Marcarelli, Andrea Nappi civil servants should prioritize raising knowledge and awareness in public procurement. Also, in order to optimize the process of financing public procurement, it is necessary to introduce advanced information systems and also stimulate suppliers to overcome legal barriers to public procurement.

Also, a research conducted by Chi were (Uzoma Cha impact of awareness, incompetence, political interference and poor monitoring of non-compliance with the legislative framework for public procurement in developing countries. Therefore, Magnon (Magnon $\left.\underline{2}_{\perp} 2 \underline{0} \underline{1} 6\right]$ reported that the reason for the low level of public procurement standards in local and central public administration is mainly due to a low level of professionalism, insufficient media coverage and nontransparency of public procurement issues, as well as significant political interference. Similarly, Sandada

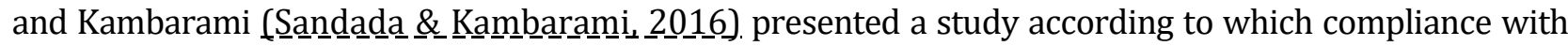
rules and political intervention are key factors for optimizing the management of public finances in process of public procurement.

A study by Lela Mélon, Rok Spruk concludes that the implementation of the public procurement optimization reform in Denmark and the Netherlands has resulted in relatively stronger controls on corruption, while a similar reform has been implemented in Portugal despite a positive and sustained impact on the quality of public procurement and regulation did not lead to increased control over corruption. In the post-reform period, the decline in the quality of public procurement regulation in Portugal is twice as high as the projected decline in the Netherlands.

The application of the relevant national legislation is the main factor in determining compliance with the strategic regulatory requirements for public procurement mentioned in this research. Sutinen and

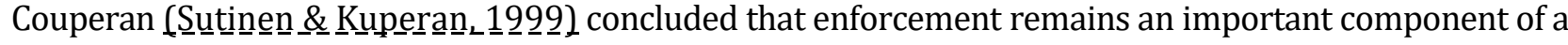
compliance regime, even with high moral obligations and social influence. Also, according to this theoretical postulate, it can be concluded that the application of public procurement regulations will oblige civil servants to behave ethically and therefore to comply with public procurement rules, which will lead to optimal management of public procurement. public finances. Researchers Sutinen and Couperan (Ś $\underline{\text { Sutinen }} \underline{\text { n }}$ \& K Kuperan $\underline{n}_{\llcorner}$1999) pointed out that people's internal engagement (ethical behavior) can be achieved through the influence of public authorities, such as the police, employers and local and central public authorities, which will eliminate individual interest in the process of financing public procurement. 
The publications of Sjors Witjes and Rodrigo Lozano point to the relationship between the share of public procurement in GDP and the purchasing power of public organizations (which is up to 19\% of GDP in European countries).

The authors of Deodat Mwesiumo, Kjetil Magnus Olsen, Geir Arne Svenning, Richard Glavee-Geo, as a result of a study of public procurement processes in Norway, concluded that financial investments, as well as costs associated with problems and obstacles to optimizing the public procurement financing system, are justified by the received higher financial benefits and results.

The content of the studies by Cecilia Bratta, Sophie Hallstedta K.-H. Robèrtab Göran Bromana, Jonas Oldmarkb ranges from: analysis of the procurement process in relation to the system for optimizing their financing and the influence of political frameworks that create obstacles to positive changes in the field of cooperation between participants in the public procurement process.

These studies are relevant for the Republic of Moldova from the point of view that the study of the process of reforming the public procurement system in developing countries and can lead to improvements in terms of optimization and development of a strategic approach that could more significantly promote innovative system solutions in support of sustainable development of public procurement in the Republic of Moldova.

Despite the fact that the emphasis of the presented studies is on the problems of organizing and financing public procurement in both developed and developing countries, as well as on the driving forces (political, social, regulatory) that hinder the integration of an effective financing system in the public procurement process, research on these issues is still limited in the context of integrating this issue into optimizing public financial management.

In the submitted publications, one can see inconsistencies in the scientific literature, which states that awareness and professionalism do not significantly affect compliance with regulatory requirements for public procurement financing, while institutional factors are very important in studies of the impact on the public procurement process. financing public procurement in terms of optimizing public financial management.

Given that the existing literature provides a limited understanding of this subject, the results of this study should be of interest to researchers, government agencies, procurement practitioners, small and medium-sized enterprises and other interested parties. In particular, the study contributes to the accumulation of knowledge about public procurement financing in the Republic of Moldova in the context of optimizing public financial management and offers practical conclusions for both practitioners and policymakers.

\section{DATA SOURCES AND USED METHODS}

The study was conducted in the Republic of Moldova with the involvement of public sector institutions. It was estimated that there are over 200 public sector institutions in the Republic of Moldova. In some of these institutions, heads of public procurement departments answered key research questions. An anonymous survey, implemented in 2019, in which more than 100 employees of government agencies and employees of private companies involved in the public procurement process took part, was based on the presentation of a number of statistical data and answers to questions about the main regulatory and systemic problems of the national public procurement system in the Republic. Moldova in the context of optimizing public financial management, which served as the basis for this study.

For the analysis of the dynamic evolution of the statistical indicators of public procurement as the number of public tenders according to the object of procurement and the value of public contracts concluded by the Public Procurement Agency (PPA) in 2018 and 2019, the method of systematic analysis was used. In order to summarize the results regarding the activity of the public procurement system in the Republic of Moldova in 2019 and 2018, the comparative analysis was used.

Literature review was guided by the PRISMA (Preferred Reporting Items for Systematic Reviews and Meta-Analyses) review method. The method of quantitative and qualitative analysis was applied to research the indicator of the share of public procurement in Gross Domestic Product (\%) and other indicators of the public procurement system in the Republic of Moldova and establish their impact to optimize finances at the macroeconomic level. A total of 6 articles from the Scopus and Web of Science databases were selected for the review. 
Data sources used for these indicators represent the data of the National Bureau of Statistics of the Republic of Moldova and the Report on the activity in the field of public procurement carried out during 2019 prepared by the PPA.

\section{THE RESULTS OF OWN RESEARCH AND DISCUSSIONS}

Based on the results of an anonymous survey employees of government agencies and employees of private companies public procurement provides for:

- covering the needs of the Republic of Moldova, at state and local level, in goods (works, services) necessary for the implementation of the functions of central and local authorities, including for the implementation of national programs for fulfilling the international obligations of the Republic of Moldova;

- the needs of public authorities, administrative-territorial units in goods (works, services) necessary for the implementation of their functions and competencies, including for the implementation of programs at local level;

- the needs of the local public administration in goods (works, services) necessary to solve the problems of local importance and to implement certain state competencies transferred to the local authorities.

With the help of the public procurement system, important tasks are solved such as respecting national security, creating and supporting state material reserves, ensuring the life of the population, etc.

From survey of heads of public procurement departments indicated, public procurement is an effective financial instrument of the state's social and industrial policy, as it allows support to be provided to domestic producers, including small enterprises, organizations, people with disabilities, etc., as well as to stimulate the production of competitive goods.

Suppliers who meet the requirements specified in the application may request a public procurement contract. This means that concluding a contract is possible with a company of any form of ownership, if it offers the most attractive conditions. A public procurement contract cannot be concluded with a company that does not meet the requirements stated by the organizers.

Public procurement or a general list of the needs of public authorities in public procurement planning procedures should be met with the most efficient allocation of budgetary funds. Efficient allocation is not so much about saving money, but about finding the best value for money. Therefore, a company that has applied to participate in a public tender must meet the customer's requirements.

Results of anonymous survey employees of private companies involved in process of public procurement show that public procurement system must also be open, transparent and accountable. Failure to comply with these requirements will lead to a breach of public procurement principles.

In some cases, the results of public procurement do not meet the stated requirements. This may be due to both the irresponsibility and lack of professionalism of the organizers and selfish reasons.

The contract for the implementation of public procurement allows the company to make a profit and offer an order for a long time, so that some participants abuse the right. However, as practice has shown, this can be treated. There are many cases where dubious decisions on signing public procurement contracts have been challenged. The joint efforts of bona fide suppliers and regulators contribute to the efficiency and effectiveness of the public procurement system.

Public procurement is necessary to provide public authorities with the necessary goods (works, services) that meet certain requirements, in the most favorable conditions for all participants in the procurement process. Both state-owned enterprises and private companies can be selected as suppliers.

For private companies that took part in the survey, public procurement of a certain type of service (work) or the provision of products can be an excellent source of income. Public procurement is beneficial to national enterprises for several reasons. First, the company gets a reliable source of sales for its products, which means that commercial costs are low.

Public procurement also guarantees the company cash flows for the services provided in full. This source of profit can be a strong incentive for the further development of the company.

In the public procurement system, entities have been identified that monitor the information in the unified information system. Based on the results of such monitoring, a consolidated analytical report shall be prepared, containing an assessment of the effectiveness of the procurement and measures to improve the legislation. This report is also published in a unified information system. 
Control over public procurement is carried out primarily by the Public Procurement Agency, the Court of Auditors and the Competition Council.

In the monitoring process, the above public authorities establish the reasons for the deviations and violations found, as well as make proposals for the elimination and improvement of the contractual system.

The following types of control are distinguished:

- interdepartmental control

- community control

- control by special regulatory authorities

The interdepartmental control is performed by the state authorities, the central and local public administration authorities, the municipal bodies, the management authorities of the public financial funds. Community control is exercised by citizens, associations of legal persons or public associations.

The institutional system of public procurement includes not only the Public Procurement Agency, the Court of Accounts, the National Council Competition Council, but also the Ministry of Finance, the State Treasury, the Financial Inspection, the National Anticorruption Center.

Therefore, the automated public procurement information system operating in the Republic of Moldova allows: saving more money for customers, increasing procurement volumes, systematizing procurement procedures, controlling not only the process of placing orders, but also the actions of suppliers and customers in the stages of concluding and executing contracts, it fully regulates the relations of all participants at all stages of the procurement process, which allows us to call the automated information system an efficient financial instrument in the public procurement system.

It should be noted that a significant disadvantage that hinders the efficient development of the public procurement system in the Republic of Moldova is the many ways in which customers and suppliers can circumvent the law and influence the outcome of the procurement procedure. One of the main imperfections is insufficient attention to the quality of the goods provided, which allows participants to give up the supply of low-quality goods.

Based on the results of an anonymous survey employees of government agencies and employees of private companies in order to continuously improve the procurement legislation, it is necessary to highlight the following directions for the development of the public procurement system of the Republic of Moldova:

- regulate and streamline anti-dumping measures in more detail;

- to take into account the specifics of the purchased goods industry (works, services) when establishing the maximum amount of an advance, as well as to regulate the practice of advance payments;

- standardization of calculation methods, monitoring the formation of initial (optimal) contract prices;

The optimization of the national public procurement system directly influences the development of the economy of the Republic of Moldova.

First of all, the national public procurement system ensures the practical fulfillment of the state's obligations to the population. These obligations are stated in government programs and, in order to fulfill them, it will inevitably be necessary to purchase the necessary goods, works or services. The public procurement system requires you to specify the purpose for which they are made before implementing them. On the other hand, it becomes possible to see where public funds are directed. And after implementing them, it allows you to compare with similar purchases made by private companies in the market and provide an objective assessment of the effectiveness of purchases.

Second, the public procurement system is an effective mechanism for the development of national private economic entities and state authorities.

Analyzing the report The report on the activity in the field of public procurement carried out during 2019, prepared by AAP we can see: during 2019 by the contracting authorities through SIA RSAP (MTender) ensuring the transparency of open public tenders, 2,229 announcements were published participation, of which:

- 451 announces - for the purchase of services.

- 594 announces - for the purchase of works and

- 1,184 announces - for the purchase of goods [4]; 
Public auction by object of procurement

Table 1

\begin{tabular}{|c|l|}
\hline 594 & Construction works \\
\hline 306 & Food \\
\hline 94 & Transport equipment and auxiliary products to transportation \\
\hline $\mathbf{9 9}$ & Oil, coal and petroleum products \\
\hline $\mathbf{1 1 7}$ & Medical equipment \\
\hline 89 & Pharmaceuticals products and reagents \\
\hline
\end{tabular}

Source: Developed by the authors based on the Report on the activity in the field of Public Procurements

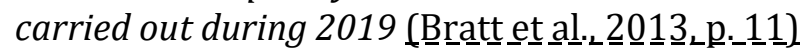

During 2019, 13,800 additional contracts and agreements were concluded by the contracting authorities as a result of public procurement procedures, compared to 2018 with 11,527 less (므므므.

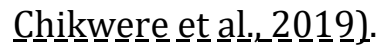

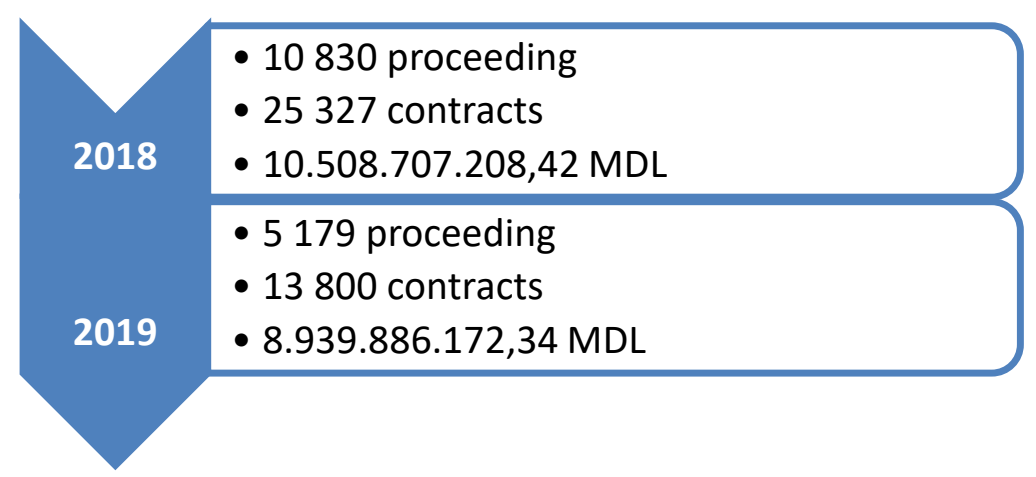

Figure 1 Aggregation of the results of 2019 and comparative analysis with the results of 2018 Source: Developed by the authors based on the Report on the activity in the field of Public Procurements

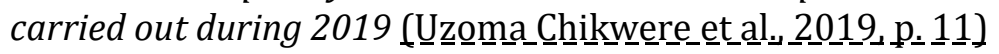

This decrease in public procurement contacts from 25327 to 13,800 units in 2019 compared to 2018, in the volume of 10508.71 million. MDL in 2018 and 8939.88 million. MDL in 2019 is explained by the fact that in Law 131/2015 were introduced the amendments regarding the increase of the application thresholds. Thus, part of the acquisitions or turned into low value public procurements.

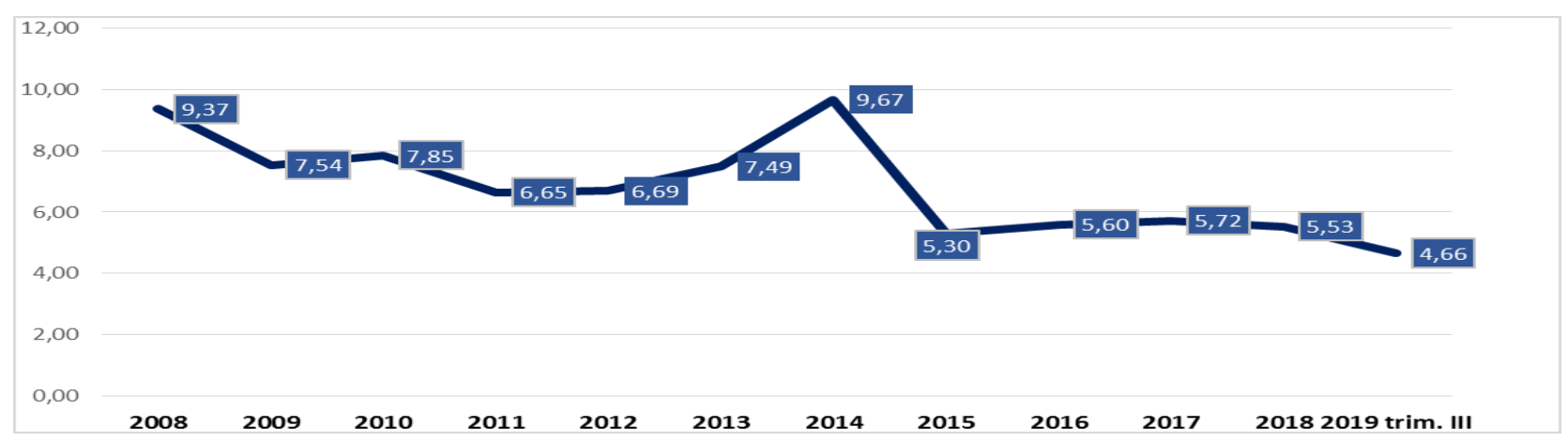

Figure 2 Share of Public Procurements in Gross Domestic Product (\%)

Source: Developed by the authors based on the Report on the activity in the field of public procurement

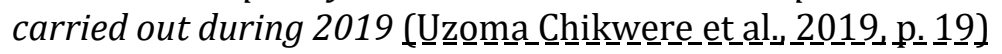

The value of public contracts concluded by the Public Procurement Agency (AAP) in 2018 and 2019 was 10,508,707,208.42 MDL and 8,939,886,172.34 MDL, representing approximately 5.53 and $4.66 \%$ of GDP. Therefore, about $5 \%$ of GDP is allocated through the public procurement market and acts as a powerful instrument of economic policy. At the same time, the public procurement system 
makes it possible to optimize the issue of competition, when the only criterion is price and the only acceptable method of procurement is tendering. The economic space has a more complex form and the aim is to provide equal conditions for the development of all types of economic entities. And the conditions for the development of a large monopoly are different from those for small businesses. Therefore, it becomes possible to move to a more complex development model, which takes into account factors such as the distribution of labor resources and territorial development. Thus, the public procurement system creates a fair economic space, in which there are opportunities for the development of all economic entities.

The public procurement system has an extraordinary anti-corruption potential. Corruption occurs when a provider seeks unfair terms, such as overvaluation. State and municipal authorities make approximately 25,327 and 13,800 purchases annually according to data from 2018 and 2019. The essential reduction of non-transparent or suspicious purchases will increase confidence in the state's activities on the market. And this will contribute to the development of private initiative and to the growth of an entrepreneurial spirit, which is so necessary in the Republic of Moldova.

The public procurement system must be efficient. Its effectiveness depends on the trust of the participants. But trust comes when a number of conditions are met.

The most important of these is the confidence that the system fulfills the functions for which it was created. When using the public procurement system, trust results from knowing its structure and respecting the principle that the attempt to "counterfeit" will inevitably result not only in the form of fines but also high risks of publicity. Another condition is the susceptibility of the system to improvements, the ability to correct the identified deficiencies.

Confidence in the system will arise if those for whom it was created are directly involved in the process of improving it. And since budgetary resources are taxpayers' funds, it is not so much civil servants that should improve the allocation mechanism, but people with the confidence of the population.

\section{CONCLUSIONS}

In order to improve the public procurement system, it is necessary to systematically and persistently eliminate the shortcomings identified by the participants in the public procurement process, in order to react significantly to gaps in legislation.

It is also necessary to have the most complete information about violations in the implementation of public procurement. It doesn't matter how the information goes. From this point of view, the existence of a public portal, which offers the possibility to post information about a procurement event that may lead to a violation of the public interest, is the best solution to this problem.

First, the information obtained must be carefully verified, recorded, classified and systematized.

Experts should determine in a timely manner whether the event occurred as a result of imperfect laws and procedures or was the result of non-compliance by officials.

Infringements resulting from non-compliance with the established rules are intended for investigations by other public authorities. If experts conclude that the influence of the "human factor" is obvious, the information should be promptly redirected to the authorized control authorities.

If the reason is in the shortcomings of the current rules, then the experts must determine the reason and propose a way to eliminate them. The task of public authorities is to analyze them carefully and, if they agree, to introduce them into legislation.

Work on improving public procurement legislation and improving the funding mechanism in this area should continue, be systemic, and should aim to increase the efficiency of budgetary expenditure by closing gaps in the practical implementation of public procurement procedures.

Optimizing funding and improving the efficiency of the public procurement process must be achieved through the transparency of information, the correction of gaps in national legislation and the absence of political influence. Creating relationships between the ethical behavior of officials, the efficiency of control and the implementation of modern information systems, will create an optimal system for financing public procurement and will improve the distribution of GDP in the Republic of Moldova. 


\section{REFERENCES}

1. Bratt, C., Hallstedt, S., Robèrt, K.-H., Broman, G., \& Oldmark, J. (2013). Assessment of criteria development for public procurement from a strategic sustainability perspective. Journal of Cleaner Production, 52, 309-316. https://doi.org/10.1016/j.jclepro.2013.02.007

2. Dennis orobo, A., \& Willy, M. (2015). Factors affecting compliance with the public procurement and disposal regulations in kenya: A case study of county government of nyamira. International Journal of Economics, Commerce and Managemnet, 3(11), 1060-1089.

3. Omagbon, P. (2016). An Assessment of Compliance with the Public Procurement Act by Nigerian Local Government. 2, 11.

4. Sandada, M., \& Kambarami, P. (2016). The determinants of the compliance to public procurement policy requirements among public enterprises in Zimbabwe. Acta Universitatis Danubius. $\quad$ Administratio, 8(1), Article $1 . \quad \mathrm{http}: / /$ journals.univdanubius.ro/index.php/administratio/article/view/3561

5. Sutinen, J. G., \& Kuperan, K. (1999). A socio-economic theory of regulatory compliance. International Journal of Social Economics, 26(1/2/3), 174-193. https://doi.org/10.1108/03068299910229569

6. Uzoma Chikwere, G., Dzandu, S. S. K., \& Dza, M. (2019). Compliance Issues with Public Procurement Regulations in Ghana. International Journal of Business and Management, 14(5), 1. https://doi.org/10.5539/ijbm.v14n5p1

Note: The article is a component part of the Research Project 20.80009.7007.15

\section{ARTICLE HISTORY}

Received 24 December 2020

Accepted 5 Mai 2021 